\title{
Você Acha que Eles Não Concordam? Sinais de variação produtiva na concordância verbal de Recife
}

\author{
They Don't Agree, Do They? \\ Signs OF VERBAL AGREEMENT PRODUCTIVITY IN RECIFE
}

Letânia Patricio Ferreira*

Resumo: O presente estudo avalia a concordância da $3^{a}$ pessoa do plural em um corpus estratificado de mulheres de classe média do Recife, analisando o comportamento de variáveis linguísticas e sociais associadas em estudos prévios à variação da concordância de número. Os resultados sugerem que, entre os fatores linguísticos, a irregularidade morfológica das construções verbais é mais relevante do que o padrão acentual dos verbos como correlato de saliência fônica. Em geral, verbos regulares e marcas de plural localizadas em sílabas átonas tendem a apresentar taxas mais elevadas de perda de concordância verbal. Os resultados sugerem que situações de pausa seguinte ao verbo parecem inibir a perda de concordância verbal. A análise dos fatores sociais do estudo demonstra que o grupo etário é mais relevante do que o nível de educação formal para explicar a variabilidade na concordância verbal. Estes resultados apoiam a hipótese da existência de um padrão produtivo de concordância de número no Português Brasileiro, como sugerido pelos resultados obtidos por Scherre e Naro (2006) e Naro e Scherre (2013) para Rio de Janeiro, bem como Yaconvenco et al. (2012) para Vitória.

Palavras-chave: Concordância verbal. Variação. Concordância produtiva.

\footnotetext{
* Doutora em Linguística pela University of Illinois at Urbana-Champaign (2008). Professora Doutora Adjunto A da Universidade Federal Rural de Pernambuco (UFRPE). Contato: letaniaferreira@gmail.com.
} 
Abstract: This study evaluated 3rd person plural agreement in a stratified corpus composed by middle class females from Recife, Brazil. The study evaluates linguistic and social variables related to number agreement variation in previous studies. Results suggest that, among the linguistic factors, morphological irregularity of verbal constructions is more relevant than accentual pattern as a correlate of phonic salience in this BP variety. Overall, regular verbs and plural markers attached to unstressed syllables tend to present higher rates of verbal agreement loss than irregular verbs and forms attached to stressed syllables. The type of segment following the verbal forms analyzed has also shown to be relevant to help explain agreement variation, as pauses seem to inhibit loss of verbal agreement. More interestingly, the social factors evaluated in the study have shown age to be more relevant than years of education in explaining verbal agreement variability. These findings support the hypotheses of a productive number agreement pattern for Brazilian Portuguese as suggested by the results obtained by Scherre and Naro (2006) and Naro and Scherre (2013) for Rio de Janeiro, as well as Yaconvenco et al. (2012) for Vitória, ES.

Keywords: Verbal agreement. Variation. Agreement productivity.

\section{Introduction}

Overall the literature points out a great variation in morphological expression of number agreement in Brazilian Portuguese (BP hereafter) depending on factors that are internal, as well as some that are external to the

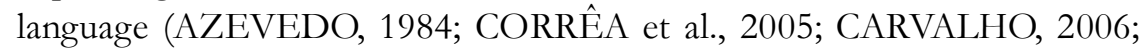
SCHERRE; NARO, 2006; CASTRO, 2007; among others).

While many scholars have suggested that number agreement in BP is being lost, others believe that the different forces involved in this linguistic phenomena will tend to hold the agreement variation stable. Recent studies suggest however that we are not dealing with a stable variation rule or the loss of number agreement in BP. On the contrary, findings from some capitals in the southwest of the country, Vitória and Rio de Janeiro, indicate that number agreement is becoming more productive in Brazil, Yaconvenco et al. (2012) and Naro and Scherre (2013) respectively. 
Based on that hypothesis we have decided to evaluate the linguistic behavior of the middle class from a third Brazilian capital, Recife. By means of the social and economic mobility mentioned by Naro and Scherre (2013) emergent groups who previously did not have access to several services and goods moved to the middle class and have developed different habits. Our goal is to investigate whether linguistic change towards a more productive verbal agreement pattern is part of the new habits of this emerging group.

Specifically, in this paper we set out to observe 3rd person verbal agreement in the BP spoken in Recife and to verify signs of a system moving towards an increase in the use of prestigious forms of agreement, which we will also call productive agreement. In general terms, we intend to verify the role of some linguistic and non-linguistic factors in the variation of number agreement in the Portuguese spoken in the capital of Pernambuco.

The article is organized as follows: In section 1, we discuss the most common internal and external factors evaluated in the study of number agreement in BP. In section 1.1 we review verbal agreement studies concerning $\mathrm{BP}$ and discuss implications related to this agreement variation. In section 2 we discuss implicationsconcerning linguistic studies, the middle class and access to education. That section is subdivided into two major subsections. Section 2.1 makes some parallels between linguistic studies and the middle class. In section 2.2 we discuss current events related to the middle class in Latin America and Brazil and their implications on social and economic mobility as well asaccess to formal education. Section 3 describes the study hypothesis while section 4 is dedicated to explaining the research methods used in the study. In section 5 we present and comment on the results. And, finally, we offera discussion of the data as well asconcluding remarks.

\section{Internal and External Factors Determining Number Agreement in $\mathbf{B P}$}

The literature suggests that at least two different number systems coexist in BP, one based on standard varieties and some non-standard variants; see Corrêa et al. (2005) and Castro (2007). Number agreement variation in BP is a complex topic of study and this variation has been considered under several aspects. Diatopic, diastratyic and diaphasic aspects of alternation have been 
pointed out in the literature. Factors internal to the language are also very relevant when explaining the way Brazilians tend to use number agreement. Overall number agreement in BP is a variable rule conditioned by both social and linguistic factors, Scherre (1994); Silva et al. (2006); Carvalho and Tondineli (2014).

Figures reported for different areas of the country show a strong diatopic variation when dialects from diverse locations are compared for nominal agreement. Azevedo (1984), for example, has documented a very high tendency towards morphological simplification and agreement loss in the southwest of Brazil. His data was collected in the rural areas of São Paulo and Minas Gerais, the Caipira dialect, and show that speakers tend to eliminate redundant plural markers over $70 \%$ of the time. Contrasting with this picture, the deletion of plural markers was found to occur at a much smaller scale in other areas of the country. Overall rates of deletion for plural markers have only been found in $29 \%$ of the noun phrase agreement data for the Portuguese spoken in Rio de Janeiro, Scherre (2001), less than half the agreement loss reported by Azevedo.

We also see a strong diatopic variation for verbal agreement. Rodrigues (1997), for example, reported 42\% lack of agreement for Rio Branco, AC; while Monguilhott and Coelho (2000) has found 21\% absence of verbal agreement in Florianópolis, SC.

Linguistic factors are also relevant for the study of both nominal and verbal agreement. Nominal agreement studies tend to be concerned with the position of the head in Determiner Phrase (DP) in relation to the other elements of the DP, see Scherre (2001). Verbal agreement studies, on the other hand, are concerned with the position of the verb in relation to the subject instead. These studies show that sentences with the post-verbal subjects tend to express lower rates of agreement than sentences where the subject precedes the verb (RUBIO, 2010).

Another linguistic aspect normally observed for both nominal and verbal agreement is phonic salience. This internal factor can be related to the accentual pattern of the target word carrying plural marking. When a word carries the plural cue in stressed syllables the token is considered more salient than words expressing plural in unstressed syllables. Phonic salience is also relative to the morphological regularity of the plural construction. 
Words exhibiting irregular plural construction such as 'lençol/ lençóis' 'sheet/ sheets' and é/são 'is/are' tend to be more salient than those presenting regular plural formation such as café/cafés 'coffee/coffees' and amava/amavam 'used to love S./P.' By consequence, studies show that words with lower phonic salience tend to present agreement loss more frequently (NARO, 1980; NARO; SCHERRE, 1998; among others).

In a study of nominal agreement, Sessarego and Ferreira (forthcoming) compare some varieties of Spanish with the Portuguese spoken in Tejucupapo, a small village located inland of Pernambuco, to find whether the type of following segment that immediately succeeds the target words can also be relevant for the application of the agreement rule. Their data suggests that agreement tends to happen more frequently when followed by a pause than when followed by a vowel or a consonant.

Many studies have been also indicating a diastratic dimension to the variation of number agreement in BP. Level of education has been pointed out by several scholars as the most relevant of the social factors to help explain number variation in this variety of Portuguese (RODRIGUES, 1997; NARO; SCHERRE, 1998; RUBIO, 2008, 2010; SOUZA, 2011). Overall these studies conclude that, despite other social factors, the more years of formal education an individual has received the higher the rate of agreement used by that person.

Recent studies have suggested, however, that age group might surprisingly be a highly relevant factor concurring with level of education to explain diastratic variation in number agreement, Scherre and Naro (2006); Yacovenco et al. (2012) and Naro and Scherre (2013), which indicate a pattern of linguistic productivity.

\section{Verbal agreement in $B P$}

The combination of internal and external language factors has been able to specifically explain verbal agreement variation as well as number agreement variation in general. An example of the significance of external factors in the explanation of verbal agreement variation is that a sizeable portion of the literature points to the diastratic dimension as the most relevant piece of the puzzle when explaining this variation; see Rodrigues 
(1997) for Rio Branco, Scherre and Naro (1998) for Rio de Janeiro, Monguilhott and Coelho (2002) for south of Brazil, Florianópolis and Rubio (2010) for São Paulo, among others. For these scholars the direct relationship between Brazilians with more years of formal education and the frequency of number agreement usage is the main variable responsible for verbal agreement variation in different parts of Brazil.

Linguistic or internal factors are also very relevant. Souza (2011), for example, evaluates the Portuguese spoken in Salvador, in the northeast of Brazil, and shows high rates of verbal agreement reaching 97\% when phonic salience and higher education are combined. The agreement rate decreases to $88 \%$ for the same group of speakers pronouncing words bearing low phonic salience. This demonstrates that linguistic elements are also very important when explaining verbal agreement variation.

Together, linguistic and non-linguistic factors show the complexity of explaining verbal agreement within a specific Brazilian community. This becomes clear when we observe the large variation of 3rd person plural agreement in a dialect that has been thoroughly described in the literature, such as the dialect spoken in the state of São Paulo. Rubio $(2008,2010)$ found that overall 3 rd person plural agreement reached $70 \%$ in the Paulista ${ }^{1}$ city of São José do Rio Preto. Also in São Paulo, Araraquara, studied by Oliveira (2010), showed an agreement of $85 \%$ for the same verbal construction. Rodrigues (2004) researched the slums of the capital of the state and only found a verbal construction agreement of $29 \%$. It is impressive to observe such different overall agreement rates for different areas within the same state even knowing that the overall agreement rates change when the data is divided based on specific factors, as we see ahead.

The 85\% reported by Oliveira (2010), for example, was first divided into two subgroups showing $96 \%$ agreement for subjects that had finished high school and $76 \%$ for subjects with only basic education. This scholar has also evaluated the relevance of phonic salience. He found that verbs carrying the morpheme responsible for agreement in stressed syllables tend to agree $95 \%$ of the time, i.e. está/ estão 'is/are.' Contrarily, those carrying agreement on unstressed syllables, i.e. falava/falavam 'used to speak S./P.,' only

${ }^{1}$ From the state of São Paulo. 
agree in $88 \%$ of the material evaluated, by consequence presenting lower agreement rates.

The 29\% overall agreement rate reported by Rodrigues (2004) comes from data collected in 1988 in the slums of São Paulo, the capital. The overall $29 \%$ agreement for third person plural makes way for a rate of $59 \%$ when the first person plural is observed instead. Formal schooling experience for Rodrigues' subjects ranged between zero to four years of formal education. Compared to Oliveira (2010)'s results, phonic salience plays an even stronger role in the results presented by Rodrigues. In her data, morphological cues for agreement based on the salient syllable exponentially strengthen agreement by over 10 times. Verbs carrying number marking in unstressed syllables tend to agree $6 \%$ of the time, as opposed to $63 \%$ for plural cues carried in stressed syllables.

All things being equal, an agreement drop from $63 \%$ to $6 \%$ due to the absence of phonic salience is very stunning. Overall, such vast variation within the same community, the state of São Paulo, helps us to contemplate the complexity of verbal agreement as a variation phenomenon. More importantly, it also serves as a reminder of how relevant it is to acquire more information about the status of this variation in other Brazilian dialects. The data from the São Paulo state demonstrate the impossibility of generalizing results obtained in one segment of the BP speaking community to other sections of it, even within the same state. For that reason we understand that further development of studies concerning number agreement variation in different dialects of Brazilian Portuguese is imperative.

Other interesting queries are also related to the study of number agreement in BP, such as: is number agreement variation a linguistic phenomenon with an end in itself or can it be correlated to other grammatical phenomena in Brazilian Portuguese? Duarte (1995), for example, claims that the reduction of the verbal paradigm in BP is pushing speakers to avoid the use of null subjects. A different side of the problem, and also a very interesting discussion in the literature, is whether the decreasing use of null subjects in BP would compromise verbal agreement. In other words, will speakers tend to rely more on verbal agreement if the sentence presents an overt subject? Rodrigues (2004), for example, believes that this could be true. The scholar reports that sentences without explicit subjects show lower tendency 
to lack verbal agreement than sentences presenting explicit subjects, $48-72 \%$. Other studies show, however, that this is not necessarily the case. With numbers pointing in the opposite direction, Souza (2011) reports a 61\% of agreement when the subject is absent, in comparison to $77 \%$ when the subject immediately precedes the verb. With two data sets pointing in opposite directions, these studies seem to indicate that the construction of sentences with absent subjects is just part of the normal practice of BP speakers. It might also be that different groups of speakers require more or less information in order to achieve proper agreement. While these issues are out of the scope of this paper, they reinforce the need to further study verbal agreement and its implications.

Another interesting question, and the main goal of this paper, concerns the status of this language variation. Is the variation involving verbal agreement in BP stable or does it show signs of productivity?

Despite the large number of studies pointing to years of education as the major social factor to explain number agreement variation in BP, recent studies point in a different direction. The alternative idea is that the patterns adopted by speakers who endured several years of schooling are not entrenched at the individual level and could spill over, influencing other speakers who did not have the same school experience, Scherre and Naro (2006). The scholars also suggest that an increase in educational opportunities as well as in social and economic mobility in the last two decades in Brazil could be helping to set this scene, Naro and Scherre (2013). In a cross-temporal analysis the scholars show that, 20 years later, 16 speakers from the same community have considerably increased their usage of number agreement. Obviously, speakers who had access to additional schooling in this timeframe show improvement in agreement rates. They were not, however, the only ones to increase their agreement rates. Speakers who have not been exposed to additional education were also using agreement more frequently. Additionally, the study shows that younger groups, who 20 years earlier showed smaller agreement rates, are now those with the highest agreement percentage. Based on these figures the scholars argue for a possible linguistic change in course in Portuguese spoken in Rio.

Naro and Scherre (2013) conclude that a linguistic shift might be taking place. They state that there is a "reversal in the general direction of shift from 
stability or loss of concord toward the acquisition of the prestige norm of full concord by the youngest speakers of the community still within the critical phase of language acquisition" (NARO; SCHERRE, 2013, p. 11). Yacovenco et al. (2012) found similar merging toward prestigious norm of full concord lead by youngsters in the dialect spoken in Vitória, ES.

While Yacovenco et al. (2012) concur that years in school is an important variable in the puzzle concerning variation in number agreement, speakers' ages seem to be an even more significant factor to explain the variation in Vitória. Similar to the case in Rio, the younger groups in Vitória are the ones showing the highest agreement rates, also indicating an age-based continuum. Interestingly, the relative weight assigned by statistical analysis to the age variable in the Vitória study is about twice as large as the weight for years of schooling. Thus confirming that age can indeed be more influential than the level of education as a social factor for agreement.

All and all it is important to keep in mind that the number agreement situation in BP is fairly diverse. However, the question we are trying to address is how is this variation organized? The results shown by Scherre and Naro (2006), Naro and Scherre (2013) as well as Yacovenco et al. (2012) indicate a sort of a rupture in the pattern of stable variation and a tendency towards a more productive agreement paradigm. The strengthening of number agreement suggested by these studies could be due to the acquisition of values of socially dominant groups. BP speakers might be approaching a more standard language variety due to social factors such as increase in education, pressure from the job market or increase in social mobility, (BORTONI-RICARDO, 2011; SOUZA, 2011).

This paper intends to observe the relevance of linguistic factors such as phonic salience, as well as to evaluate level of education versus generation as possible main social factors to help explain number agreement variation in the Portuguese spoken in Recife. In a broader perspective we intend to answer the question of whether we are dealing with a stable variation based on a well-defined social pyramid headed by education, or if agreement is indeed prone to production at this specific point in the history of the Portuguese spoken in Recife. 


\section{Linguistic Studies, Middle Class and Access to Education}

\section{Linguistic studies and middle class}

Most of the work done in linguistics has historically been concerned with describing and studying standard language. In Brazil such lines of studies have given rise to the NURC (Norma Linguística Urbana Culta) project across the country in the 70's, with the main goal to document and study the Portuguese language as spoken by well-educated speakers in urban areas of Brazil. With the development of the generative grammar, which had Chomsky as one of its main proponents, syntactic studies have developed some sort of autonomy from reporting the frequency of use of a specific construction or the possible variations of what a speaker has said. This line of study sometimes focuses on when a subject produces speech in a given way, especially when it differs from a standard variety. This licenses scholars to report on that particular form despite its frequency of use or the number of speakers who actually use that form. With that information, researchers focus on explaining the parameters and constraints that have driven the speaker to use such a way of producing language.

As a consequence, several of the studies dealing with BP number agreement, especially in syntax, describe the difference between the standard and non-standard plural varieties. Meanwhile, the linguistic analysis in these studies tends to focus on the extreme degrees of change in the syntactic structure. In the case of number agreement in BP this means loss, see Costa (2006) among others. This strategy allows studies to attain more impact as the varieties that have been compared lie on the opposite sides of the scale but leave a large gap in between the two opposite linguistic forms. While the goal of this line of study may be to describe linguistic processing it somehow fails in describing how frequently a given linguistic process applies in society. A disadvantage in looking at number agreement with that perspective is that it makes it impossible to measure the relevance of such linguistic form to a given language community.

Other lines of linguistic analyses such as variation studies, which has William Labov as one of its most notable names, pay closer attention to stratification and frequency of use. Fortunately, many programs in Brazilian 
public universities have been developing new databases and analyses using this model. Such is the case of Vertentes do Portugês Popular do Estado da Bahia, a project developed in 2002 to study the language spoken in Bahia. Portvix, a project, which documents and evaluates the language spoken in Vitória - ES is another example of it. There are several other projects concerned with language variation, such as the Iboruna Project, which focus on the Portuguese spoken in the inlands of the state of São Paulo. One of the advantages of variation studies is that it removes the emphasis from the extreme linguistic forms and focuses on evaluating language as naturally spoken by the different layers of a community.

While we are glad to see the spectrum of linguistic research broadening into a more comprehensive scope of varieties it is undeniable that, for a long time, linguistic studies have been so centered on extremes that they have paid little attention to the language spoken by the middle class.

It is our understanding that investigating middle class linguistic behaviors can present several advantages. Middle class individuals have continuous interaction with both high and low class speakers; optimizing the amount of variation to which they are exposed. Additionally, middle class individuals are also probably the social group most susceptible to fluctuations in economic status within a lifetime. That makes this group a good indicator of social and linguistic trends that may be in progress. One of the current developments involving the middle class in recent years in Brazil is related to income inequality and economical growth, which seems to have possibly had an impact in the way Brazilian people are speaking. For these reasons, we chose to focus on the language spoken by the middle class in the current study.

\section{Middle class and access to formal education}

According to The Economist ${ }^{2}$ the Brazilian middle class has expanded 50\% between 2003 and 2009 which "represents extraordinarily rapid social growth" in line with the growth of Latin America in general.

In Brazil, social mobility is key to the acquisition of standard linguistic patterns (BORTONI-RICARDO, 2011, p. 22). Social mobility is not,

\footnotetext{
${ }^{2}$ Avaible in $<$ http://bit.do/bFatX $>$.
} 
however, an isolated event in and of itself. Other interesting social movements, such as increasing access to education, tend to influence linguistic behavior and social mobility. In the last two decades "the average number of years of school attendance among young Latin Americans has increased sharply, reducing the social gap generated by social class", says The Economist. Despite recognizing a big difference in the quality of the schools attended by the rich and by the poor the magazine also adds that higher education, which tends to be a "passport to middle class" is also expanding in that part of the continent.

In general, the literature seems to concur that education is a key piece in the puzzle to explain a historically low intergenerational mobility in Brazil in comparison to other countries; while indicating that additional years in school can be translated into a significant increase in the wage of employees, see Azevedo (2014). The evaluation of the recent decades, however, suggests an undergoing shift in the low intergenerational mobility that used to characterize Brazil. According to Hailu (2009), the Brazilian workforce has been getting more access to education. The scholar adds that improvements in education are one of the main causes for the decrease of inequality that has been taking place in Brazil; which according to him has dropped from .59 in 2001 to .53 in 2009.

Certainly, the situation faced by Brazil is not brand new or even particular to this country. In a report for the World Bank, Fredricksen (1990) reviews the progress of primary education in developing countries in the last 3 decades prior to the study, showing that the rates of school enrollment in Latin America had impressively increased since the 60's. The researcher adds that back in 1980 the existing enrollment capacity for first grade in Latin America had been reported as $86 \%$ for the number of children of official age to engage in school and these numbers have been largely affected by Brazil ${ }^{3}$. In addition, studies indicate that the Brazilian government has continuously invested in public politics to urge individuals to have more access to education (AZEVEDO, 2014).

\footnotetext{
${ }^{3}$ The scholar advises caution when examining these numbers as evidence suggests that the figures are artificially higher than they should due to instances of double counting of first grade students as well as underestimation of the level of repetition.
} 
Overall it seems that education is deeply associated with economic growth. Several studies have found that accumulation of human capital has an important role in economic growth as well as in the growth of a country's productivity and innovation. This, in turn, would justify government subsides for education, Lucas (1987) as well as Macedo e Silva (2014). Classic economic studies have also shown a strong positive correlation between the number of students enrolled in secondary education and countries' GDP, ie, Mankwin et al. (1990).

\section{Study Hypotheses}

With all of that in mind, we wonder what to expect for the linguistic behavior of the middle class in Recife with regards to verbal agreement. We recorded speakers from a community (3 neighborhoods in the vicinity of each other: Várzea, Jardim São Paulo and Torrões) based in a specific area of the metropolitan region of Recife. Bezerra (1995) and Carvalho (2007) subdivide the central neighborhoods of Recife into six political and administrative regions. The 3 neighborhoods surveyed in this research belong topolitical and administrative regions 4 and 5, which are described by the researchers as middle class neighborhoods that had problems with infrastructure and services.

We expect to see some linguistic repercussions for the speakers given the profile of the neighborhoods evaluated in this study and considering that the Brazilian middle class has been flourishing in the last few decades, as explained in a next section. The idea is that an increase in economic power associated with more exposure to different types of media, more access to educational opportunities as well as more prospects for jobs might be pushing the BP spoken by the middle class towards a more standard BP variety (BORTONI-RICARDO, 2011; SOUZA, 2011). Based on that, we question if we are faced with a stable variation for number agreement or whether the data will be inclined towards a productive pattern in verbal agreement.

\section{Methods}

We recorded 11 female speakers (five children and six adults) from the community described above. At the time of the interview, the five children 
ranged between 8 and 10 years old and went to school $\left(3^{\text {rd }}-5^{\text {th }}\right.$ grade $)$ in the same community. The six adults were evenly subdivided into two different groups. Three of them were $25-40$ years old and in the job market; the other three were $65-75$ years old and retired.

The interviewing process started by collecting data from 3 speakers from each group. Adults seem to have had an easier time with the task, being very creative and producing a large amount of data. The number of sentences produced by the children in the same task, however, was drastically inferior to the amount of data obtained from adults. In an attempt to achieve a more balanced dataset we interviewed 2 additional children for the study as extreme lack of proportionality in data can distort statistical results, see Guy and Zilles (2007).

The task consisted of subjects describing drawings presented to them. Overall, the drawings illustrated one single person/animal or a group of people/animals performing a specific action (for example, ice skating). The drawings were presented to subjects in two different rounds. In the first round participants were asked to report who they see in the picture and which things they think that the subject(s) in the pictures normally do. The researcher walked the volunteer trough a trial round showing 2 pictures and asking: "who is this?" "What does he/she/it normally do?" In the second round, speakers were asked to mention the subject of the picture and describe the specific action that is occurring in that particular illustration. The questions the researcher asked in these particular situations were: "who is this?" and "What is he/she or it doing?"Therefore the task elicited both 3rd person plural present tense (elas comem 'They eat') and present progressive (eles estão comendo 'They are eating'). Images were never repeated and speakers commented on different images each time.

In this paper we observe the frequency of agreement only for the first verb immediately related to the subject of the sentence. In sentences such as eles voam e depois querem se refrescar 'they fly and afterwards [they] want to refresh themselves' only the italic part of the sentence was considered in the analysis. In order to simplify the experiment we neutralized possible differences due to the position of the verb in relation to the subject by only evaluating sentences where the subject precedes the verb. The results presented in section 5 focus on 3rd person subject and verbal agreement. 


\section{Results}

This section presents the results of the experiment from two different angles: internal and external factors. First, we observe that the middle class speakers from Recife demonstrate high agreement rates when we consider that Table 1 shows a lack of agreement, which only ranges between 2-13\% independent of the category analyzed. Despite running all data together in Goldvarb at once we decided to show the results for linguistic and nonlinguistic factors separately in order to facilitate data comprehension. This explains why both tables present the same input: log likelihood and significance. Linguistic factors are exposed in Table 1 and non-linguistic factors are shown in Table 2.

We start by discussing the internal aspects considered for the study. Table 1 presents the data distribution for three linguistic factors: (i) verbal STRESS pattern indicates whether verbs express the plural on stressed or unstressed syllables, (ii) VERB TYPE designates whether the evaluated third person plural form is a regular or irregular verb and (iii) FOLLOWING SEGMENT intends to verify whether having a consonant, a vowel or a pause after the plural mark would help determining verbal agreement.

The figures relative to type of STRESS show that lack of agreement tends to be highly reduced when the plural is formed on stressed syllables. In these types of syllables agreement fails to happen only $3 \%$ of the time as opposed to $11 \%$ when number is expressed on unstressed syllables, about four times more. Factor weight, however, does not seem to indicate a high relevance for this linguistic element as it shows a small difference between stressed and unstressed syllables, .42 versus .55 .

On the contrary, we see that the factor weight for regular verbs is highly inferior to that relative to irregular verbal forms, .21 versus .65. This goes to show that verbal regularity is highly relevant for verbal agreement. The data also show that irregular forms lack agreement quite sporadically, only $2 \%$ of the time, while regular verbs tend to lack agreement more frequently, $13 \%$ of the time.

The third internal factor considered in Table 1 is FOLLOWING SEGMENT. The results indicate that a following pause tends to inhibit lack of agreement. This linguistic variable presents the highest weight among all other linguistic factors, .70, showing that it is highly relevant. 
Table 1 - Variable rule analysis of the contribution of internal factors to the probability of lack of subject-verb agreement.

\begin{tabular}{|l|c|c|c|c|}
\cline { 2 - 5 } \multicolumn{1}{c|}{} & $\begin{array}{c}\text { Factor } \\
\text { Weight }\end{array}$ & $\begin{array}{c}\text { \% Lack of } \\
\text { agreement }\end{array}$ & N & \%data \\
\begin{tabular}{|l|c|c|c|c|}
\hline STRESS & 3 & 344 & 63 \\
\hline Stressed & 0.42 & 11 & 201 & 37 \\
\hline Unstressed & 0.55 & 13 & 175 & 32 \\
\hline VERB TYPE \\
\hline Regular verbs & 0.21 & 2 & 370 & 68 \\
\hline $\begin{array}{l}\text { Irregular } \\
\text { verbs }\end{array}$ & 0.65 & 4 & 365 & 65 \\
\hline FOLLOWING SEGMENT & \multicolumn{4}{l}{} \\
\hline Consonant & 0.51 & 4 & 93 & 17 \\
\hline Vowel & 0.27 & 13 & 96 & 18 \\
\hline Pause & 0.70 & 4 & & \\
\hline
\end{tabular}
\end{tabular}

$($ Total $=545 ;$ Log likelihood $=-96.317 ;$ Significance $=0.008 ;$ Input 0.972) .

By observing the non-linguistic factors in Table 2, a closer look at level of EDUCATION does not show a highly remarkable difference between the factor weight for basic and high education, .41 versus .53. The percentages of lack of agreement confirm the small difference between the two groups. Subjects with higher education perform slightly better than subjects with only a basic education, $5 \%$ versus $7 \%$ agreement deletions.

Generation, on the other hand, brings an interesting complement to the picture. The numbers show that the $60+$ speakers favor lack of number agreement the most ( $12 \%$ with a .25 factor weight). On the other side of the scale we find the working age adults, 25-40 years old, disfavoring lack of agreement $(2.2 \%$ and .72 factor weight). Children between $8-10$ years old are placed in between the two groups, with a $7 \%$ deletion rate and a .32 factor weight. 
Table 2 - Variable rule analysis of the contribution of external factors to the probability of lack of subject-verb agreement.

\begin{tabular}{|c|c|c|c|c|}
\hline & $\begin{array}{c}\text { Factor } \\
\text { Weight }\end{array}$ & $\begin{array}{l}\% \text { Lack of } \\
\text { agreement }\end{array}$ & $\mathbf{N}$ & $\%$ data \\
\hline \multicolumn{5}{|c|}{ EDUCATION } \\
\hline $\begin{array}{l}\text { Basic } \\
\text { Education }\end{array}$ & 0.41 & 7 & 134 & 25 \\
\hline $\begin{array}{l}\text { Higher } \\
\text { Education }\end{array}$ & 0.53 & 5 & 411 & 75 \\
\hline \multicolumn{5}{|l|}{ AGE } \\
\hline $8-10$ & 0.32 & 7 & 134 & 25 \\
\hline $25-40$ & 0.72 & 2 & 273 & 50 \\
\hline $60+$ & 0.25 & 12 & 138 & 25 \\
\hline
\end{tabular}

$($ Total $=545 ;$ Log likelihood $=-96.317 ;$ Significance $=0.008 ;$ Input 0.972) .

Interestingly, children who have only made it to the 5th grade are presenting more noteworthy agreement rates than the third generation, which has endured the full educational cycle to obtain a college degree.

An interesting remark about the data is that AGE is the variable that presents the highest factor weight not only between the non-linguistic variables, but also among all internal and external variables in the same Goldvarb run, .72. This indicates that age is the most relevant factor to explain verbal agreement variation in this group. The results are highly significant as p-value is $=0.008$.

These results differ from Scherre and Naro (1998), Monguilhott and Coelho (2002), Rodrigues (2004) and others who indicated level of education as the most relevant social factor to explain number agreement. They do, however, show the same trends suggested by Scherre and Naro (2006), Yacovenco et al. (2012) and Naro and Scherre (2013) indicating that age is the most important social variable to explain number agreement in BP. 


\section{Discussion}

This paper has focused on the study of 3rd person plural agreement in the Portuguese spoken by a middle class group of females from Recife, Brazil. The results of the study confirm that verbal agreement rule is prone to variation. Overall rates of agreement for this dialect are shown to be always superior to $87 \%$, reaching up to $98 \%$ depending on some linguistic and external factors relevant to this variation.

It is important to take in consideration that the present results reflect 3rd person agreement in the BP under the conditions of this experiment and for the specific sociolect evaluated in this study. Variations in the data collection methodology and group studied may yield different results.

Among the linguistic parameters related to the variation we have observed STRESS, VERB TYPE and type of the FOLLOWING SEGMENT. The study of the accentual pattern shows that verbs holding a plural marking in stressed syllables tend to present a much higher percentage of agreement than verbs that carry a plural marking in unstressed syllables, $3 \%-11 \%$. The factor weight however indicates that stress is not highly relevant in helping us predict potential deletion situations for verbal agreement.

The higher frequency of agreement in irregular verbal forms confirms Naro (1981)'s hypothesis that phonic salience is an important internal factor to predict number agreement patterns in BP. The greater level of markedness in the morphological construction of irregular verbs tends to render them more salient to agreement production as predicted by the scholar.

The study of the type of segment immediately following the target words shows that pause is a phonological environment that helps to maintain agreement. Data shows that, when followed by a pause, agreement tends to happen more frequently than when followed by consonants or vowels. These results confirm the findings of Sessarego and Ferreira (forthcoming) for the dialect spoken in Tejucupapo, Pernambuco. The combination of these findings demonstrates a common linguistic trait shared between nominal and verbal agreement of dialects spoken in this northeastern Brazilian state. It also indicates synchronic behavior between the rural and the urban dialects spoken in Pernambuco. While the observation of the phonological environment following verbal forms is a very common practice in the studies 
of number agreement in Spanish, see for example Poplack (1980) and Carvalho (2006), Portuguese studies do not seem to pay much attention to this linguistic factor. Further studies are therefore needed in order to verify the relevance of pause as a phonological environment to help withholding agreement loss in BP for other dialects.

The analysis of social factors calls our attention to the interaction between the EDUCATION and AGE groups. As mentioned above, many studies concerning either BP number agreement in general or verbal agreement specifically have identified level of education as the most relevant social factor helping explain agreement variation in BP. When including age as a variable, these studies normally concluded that it is not a relevant parameter in comparison to level of education. This led scholars to suggest a stable variation or even possible loss of number agreement in BP.

A couple of studies based on data collected after the year 2000 have controversially pointed toward a higher relevance on the age factor showing signs of a possible linguistic change. One of the main goals of this experiment was to observe the interplay between age and level of education in order to verify this hypothesis. The results show, as expected, that subjects with a college degree have, in general, surpassed agreement rate of those with only basic education. It is impressive, however, that the two groups differ by only $2 \%$ in agreement rates, $7 \%-5 \%$. The fact that children with only a basic education show lower rates for agreement loss than the third generation, who hold college degrees, is even more impressive. The data show that children fail to agree $7 \%$ of the time, while the $60+$ group lacks agreement $12 \%$ of the time despite having a higher level of education.

It is also interesting that the statistical program has selected AGE as the most relevant factor among all linguistic and non-linguistic parameters evaluated in the present study. That comes to support the findings of Scherre and Naro (2006), as well as Yacovenco et al. (2012) and Naro and Scherre (2013), which indicate verbal agreement productivity as younger generations seem to be leading the way in acquisition of prestigious verbal agreement patterns.

Naro and Scherre (2013) hypothesize that social change in Brazil has spurred an increase in education as well as in economic and social mobility. As a result, this social change is, according to them, one of the reasons behind 
this linguistic phenomenon. In the present study we tried to obtain more information to verify this hypothesis and we found strong support for it in studies related to the economical and social trends in Brazil and Latin America. In agreement with this theory, among the groups studied here, working age speakers would be more susceptible to social pressure. Linguistically, that would result in better agreement rates for the second generation, as shown by the present data.

While social mobility and increase in education have been pointed out as the main motivations for working age speakers to show a higher productivity in verbal agreement, there is still a gap in explaining the linguistic behavior of the children in this study.

To Labov (1989), all things being equal, in a situation based on social variability, language learners will tend to acquire the patterns characterized by their parents' speech. The fact that children with a much lower educational background have higher agreement rates than the third generation, who hold college degrees, supports Labov (1989)'s theory. This suggests that children could be acquiring verbal agreement patterns from their parents, who belong to the working age group, showing agreement productivity in the community.

Further research is necessary in order to verify if the same trend can be duplicated in other communities. Additional studies are also required in order to monitor this linguistic situation in the three capitals of Brazil that have reported these productive patterns so far; Rio, Vitória and Recife. Further studies would yield a more comprehensive evaluation of the direction of number agreement for the years to come.

\section{Acknowledgments}

This research received founding from Conselho Nacional de Desenvolvimento Científico e Tecnológico and Fundação de Amparo à Ciência e Tecnologia do Estado de Pernambuco(DCR-0085-8.01/12). 


\section{References}

AZEVEDO, M. Loss of agreement in Caipira Portuguese. Hispania, v. 67, p. 403-409, 1984.

AZEVEDO, M. D. Mobilidade intergeracional na Educação. O caso dos alunos da Universidade Federal do ABC. 2014. Projeto de Pesquisa Universidade Federal do ABC, São Bernardo do Campo.

BEZERRA, M. L. Os instrumentos de ordenamento e desenvolvimento urbano da cidade do Recife: aplicabilidade e eficácia. Caderno de Estudos Sociais, v. 11, n. 1, p. 5-18, 1995.

BORTONI-RICARDO, S. Do campo para a cidade: estudo sociolinguístico de migração e redes sociais. São Paulo: Parábola, 2011.

CARVALHO, A. Nominal number marking in a variety of Spanish in contact with Portuguese. In: KLEE, C. L.; FACE, T. (Eds.). Selected Proceedings of the $8^{\text {th }}$ Hispanic Linguistic Symposium. Somervill, MA: Cascadilha, 2006. p. 154-166.

CARVALHO, K.; TONDINELY, P. A variação sintática na construção das falas no município de Janaúba em relação à concordância verbal: uma abordagem sociolinguística. Sociodiolecto, v. 5, p. 71-95, 2014.

CARVALHO, S. C. de. Estudo variável do apagamento dos ditongos decrescentes orais na fala do Recife. 2007. Dissertação (Mestrado em Linguística) - Universidade Federal de Permanbuco, Recife.

CASTRO, A. O processamento da concordância de número interna ao DP por crianças de 2 anos falantes de português europeu. In: ENCONTRO DA ASSOCIAÇÃO PORTUGUESA DE LINGUÍSTICA, 22.,2007, Lisboa. LOBO, M.; COUTINHO, M. (Eds.). Anais... Lisboa: Colibri, 2007. p. 211-221.

CORRÊA, L.; AUGUSTO, M.; FERRARI-NETO, J. The early processing of number agreement in the DP: Evidence from the acquisition of Brazilian Portuguese. In: BOSTON UNIVERSITY CONFERENCE ON 
LANGUAGE DEVELOPMENT, 30., 2005, Boston. BAMMAN, D. et al. (Eds.). Anais... Boston, 2005.

COSTA, J.; SILVA, M. Nominal and verbal agreement in Portuguese: An argument for distributed morphology. Studies on agreement, p. 25-46, 2006.

DUARTE, M. E. A perda do princípio "Evite Pronome" no português brasileiro. 1995. Tese (Doutorado em Linguística) - Universidade Estadual de Campinas, Campinas.

FREDERICKSEN, B. Increasing foreign aid for primary education: The challenge for Donors. In: WORKSHOP ON BASIC EDUCATION ORGANIZED BY THE NATIONAL INSTITUTE OF EDUCATIONAL PLANNING AND ADMINISTRATION, 1990. New Delhi, 1990. (Oral Presentation).

GUY, G.; ZILLES, A. Sociolingüistica quantitativa: instrumental de análise. São Paulo: Parábola, 2007.

LABOV, W. The child as Linguistic Historian. Language Variation and Change, v. 1, p. 85-94, 1989.

HAILU, D. What explains the decline in Brazil's inequality. One Pager, v. 89, July 2009. Disponível em: <http://bit.do/bFatD>. Acesso em: 10 mar. 2015.

LUCAS JR., R. On the mechanics of economic development. Journal of Monetary Economics, v. 22, n. 1, p. 3-42, 1988.

MACEDO E SILVA, L. Qual a importância da educação para o desenvolvimento econômico? 2014. Monografia. Universidade Federal do ABC, São Bernardo do Campo.

MANKIW, N.; ROMER, D.; WEIL, D. A contribution to the empirics of economic growth. The Quarterly Journal of Economics, v. 107, n. 2, p. 407-437, 1992.

MONGUILHOTT, I.; COELHO, I. Um estudo da concordância verbal de terceira pessoa em Florianópolis. In: VANDRESEN, P. (Ed.). Variação e mudança no português falado na região sul. Pelotas: Educat, 2002. p. 189-216. 
NARO, A. The social and structural dimensions of a syntactic change. Language, v. 57, p. 63-98, 1981.

NARO, A.; SCHERRE, M. Remodeling the age variable: Number concord in Brazilian Portuguese. Language Variation and Change, v. 25, p. 1 15, 2013.

OLIVEIRA, N. C. A concordância verbal na região noroeste do Estado de São Paulo. 2010. Dissertação (Mestrado em Linguística e Língua Portuguesa) Universidade Estadual Paulista Júlio de Mesquita Filho, Araraquara.

POPLACK, S. Deletion and desambiguation in Puerto Rican Spanish. Language, v. 56, n. 2, p. 371-385, 1980.

RUBIO, C. F. A concordância verbal na lingua falada na região Noroeste do Estado de São Paulo. 2008. Dissertação (Mestrado em Estudos Linguísticos) - Universidade Estadual Paulista Júlio de Mesquita Filho, São José do Rio Preto.

RUBIO, C. F. Regularidades no fenômeno da concordância verbal em variedades do português brasileiro: estudo sociolinguístico comparativo. Estudos linguísticos, São Paulo, v. 39, n. 2, p. 602-616, maio/ago. 2010.

RODRIGUES, A. Concordância verbal, sociolingüística e história do português brasileiro. Fórum, v. 4, p. 115-145, 2004.

RODRIGUES, D. A. A concordância verbal na fala urbana de Rio Branco. 1997. Dissertação (Mestrado em Linguística) - Universidade Estadual de Campinas, Campinas.

SCHERRE, M. Aspectos da concordância de número no português do Brasil. Revista Internacional de Lingua Portuguesa, v. 12, p. 37-49, 1994.

SCHERRE, M. Phrase-level parallelism effect on noun phrase number agreement. Language Variation and Change, v. 13, p. 91-107, 2001.

SCHERRE, M.; NARO, A. Sobre a concordância de número no português falado do Brasil. In: CONGRESSO INTERNAZIONALE DI LINGUISTICA E FILOLOGIA ROMANZA, 21., 1998, Palermo. Atti... 1998. p.509-523. 
SCHERRE, M.; NARO, A. Mudanças em mudança: a concordância de número no português brasileiro. Scripta, v. 9, p. 107-129, 2006.

SOUZA, C. M. B. de. Variáveis estruturais: efeitos na concordância verbal do português falado em Salvador. In: SIMPÓSIO INTERNACIONAL DE LETRAS E LINGUÍSTICA - SILEL, 2., 2011, Uberlândia. Anais do SILEL, v. 2, n. 2. Uberlândia: EDUFU, 2011. p 1-13.

SESSAREGO, S.; FERREIRA, L. (fortcoming), Spanish and Portuguese parallels: Impoverished number agreement as a vernacular feature of two rural dialects. In: SESSAREGO, S.; TEJEDO, F. (Eds.). Spanish language and sociolinguistics analysis. Amsterdan; Philadelphia: John Benjamins.

THE EXPANDING middle. The Economist, 2012. Disponível em: < http://bit.do/bFatX>. Acesso em: 15 abr. 2015.

YACOVENCO, L. et al. Projeto Portvix: a fala de Vitória/ES em cena. Alfa, v. 56, p. 771-806, 2012.

Recebido em: 30/05/2015

Aceito: 17/11/2015 